\title{
Skrzyżowania z wyspą centralną - przepustowość, warunki ruchu oraz wpływ na klimat akustyczny
}

\author{
Marek Motylewicz \\ Zakład Inżynierii Drogowej, Wydział Budownictwa i Inżynierii Środowiska, \\ Politechnika Białostocka,e-mail: m.motylewicz@pb.edu.pl
}

Streszczenie: Skrzyżowania z wyspą centralną są rozwiązaniem proponowanym w wytycznych projektowania dróg głównie z uwagi na występowanie dużych, wewnętrznych powierzchni akumulacji dla pojazdów skręcających w lewo, które odpowiednio zaprojektowane zapewniają wysoką przepustowość całego rozwiązania. W ostatnich latach, z uwagi na dynamiczny wzrost ruchu i pogorszenie jego warunków, w wielu polskich miastach, w tym również w Białymstoku, obserwuje się przebudowę istniejących skrzyżowań na skrzyżowania z wyspą centralną. Poprawne funkcjonowanie tych skrzyżowań zależy od parametrów programu sygnalizacji świetlnej oraz przepustowości wewnętrznych powierzchni akumulacji, która powinna być większa od natężeń relacji skrętu w lewo. W artykule zaproponowano sposób sprawdzania przepustowości tych powierzchni w przypadku wielofazowych programów sygnalizacji świetlnej a przykładowe obliczenia poparto wynikami mikrosymulacji ruchu. Wykonano również obliczenia porównawcze przepustowości skrzyżowań $\mathrm{z}$ wyspą centralną, rond i skrzyżowań bez sygnalizacji świetlnej. W artykule zamieszczono również analizę wpływu skrzyżowań z wyspą centralną na hałas $\mathrm{w}$ ich otoczeniu $\mathrm{w}$ odniesieniu do wyników pomiarów równoważnego poziomu dźwięku w otoczeniu innych typów skrzyżowań.

Słowa kluczowe: skrzyżowanie, wyspa centralna, rondo, przepustowość, hałas.

\section{Wprowadzenie}

Skrzyżowania drogowe są nieodłącznym i newralgicznym elementem każdej sieci drogowej. Natężenie ruchu pojazdów, które jest większe od przepustowości skrzyżowania powoduje nie tylko pogorszenie warunków ruchu w jego obrębie ale przekłada się również na pogorszenie funkcjonowania większego obszaru sieci drogowej. Skutkuje to wzrostem średnich strat czasu ponoszonych przez pojazdy oraz zwiększeniem liczby zatrzymań i długości kolejek co z kolei prowadzi do wzrostu emisji spalin oraz wzrostu poziomów hałasu [1, 2]. Z tych powodów ważnym jest odpowiednie „dopasowanie” rozwiązania geometrii i organizacji ruchu skrzyżowania względem prognozowanego natężenia ruchu pojazdów jakie skrzyżowanie będzie musiało przenieść. W przypadku dużych natężeń ruchu osiągających wartość około $8000 \mathrm{P} / \mathrm{h}$, skrzyżowaniem, które zapewnia tak wysoką przepustowość jest skrzyżowanie z wyspą centralną [3]. Jego zaletą jest również możliwość przeniesienia dużych natężeń relacji skrętu w lewo.

Skrzyżowanie z wyspą centralną jest jednym z rodzajów skrzyżowań skanalizowanych funkcjonujących w oparciu o sterowanie sygnalizacją świetlną. Powstaje ono poprzez rozsunięcie jednokierunkowych jezdni w obszarze krzyżujących się ulic i wybudowanie owalnej lub kołowej wyspy centralnej o średnicy w zakresie przeważnie od 30 do $60 \mathrm{~m}$. 
Duże rozmiary wyspy centralnej powodują utworzenie wewnątrz skrzyżowania czterech powierzchni akumulacji dla pojazdów skręcających w lewo. Cechuje je duża przepustowość wynosząca zwykle od 250 do 600 P/h, która zależy głównie od średnicy wyspy centralnej, liczby pasów ruchu poprowadzonych dookoła tej wyspy oraz długości cyklu sygnalizacji świetlnej [4]. Rzeczywista przepustowość powierzchni akumulacji może zostać zwiększona dzięki odpowiednim modyfikacjom programu sygnalizacji świetlnej (wydłużenie długości światła zielonego na przebiegu dominujących relacji skrętu w lewo) $[5,6,7]$ lub znacznie ograniczona w wyniku przebiegu linii tramwajowej przez skrzyżowanie $[8,9]$ lub poprzez niewłaściwą organizację ruchu i zachowania kierowców [10].

Pod względem organizacji ruchu, skrzyżowania z wyspą centralną są porównywane do zespołu czterech skoordynowanych ze sobą sub-skrzyżowań jednokierunkowych jezdni zlokalizowanych na niewielkiej przestrzeni [11]. Ich sprawne funkcjonowanie oraz brak zatłoczenia wewnętrznych powierzchni akumulacji, gwarantują wysoką przepustowość całego układu. Standardowym rozwiązaniem jest wyposażenie tego typu skrzyżowań w 2fazową sygnalizację świetlną lecz w przypadku dużych natężeń ruchu, w szczególności na relacjach skrętu w lewo, stosuje się wielofazowe programy sygnalizacji świetlnej. Pozwala to na poprawę przepustowości krytycznych relacji oraz umożliwia elastyczne sterowanie grupami kołowymi i pieszymi na wlotach, wylotach oraz zatokach akumulacji skrzyżowania. 2-fazowe programy sygnalizacji świetlnej zasadniczo pozwalają jednak na uzyskanie największych przepustowości skrzyżowania $\mathrm{z}$ wyspą centralną ale przy stosunkowo równomiernym rozkładzie ruchu na skrzyżowaniu i braku zatłoczenia wewnętrznych powierzchni akumulacji. W tym przypadku powstaje również konflikt pomiędzy możliwością zapewnienia jednorazowego przejścia pieszego przez wlot i wylot i jego długością a przepustowością wewnętrznych powierzchni akumulacji [3]. Powiększanie wyspy centralnej i skracanie długości cyklu sygnalizacji prowadzi do wzrostu przepustowości zatok akumulacji ale jednocześnie wydłuża drogę przejścia pieszego przez wlot i wylot skrzyżowania i uniemożliwia przejście w jednym cyklu sygnalizacji.

Biorąc pod uwagę kształt wyspy centralnej, geometrię wlotów i organizację ruchu, skrzyżowania z wyspą centralną charakteryzują się dużą różnorodnością rozwiązań, odznaczających się wieloma zaletami oraz pewnymi wadami [12, 13, 14]. Uzyskanie wysokiej przepustowości i dobrych warunków ruchu uwarunkowane jest jednak często dość rozbudowanym rozwiązaniem geometrii w planie co powoduje, że skrzyżowania z wyspą centralną zajmują dużo większą powierzchnię terenu niż inne typy skrzyżowań. Powoduje to przybliżanie pasów ruchu, a tym samym źródeł hałasu, w kierunku zabudowy co jest niepożądanym efektem wyboru tego typu skrzyżowania. Z uwagi na możliwość przeniesienia bardzo dużych natężeń ruchu, przy których na innych typach skrzyżowań zostanie przekroczona przepustowość i wystąpią złe warunki ruchu, skrzyżowanie z wyspą centralną może okazać się jednak lepszym rozwiązaniem pod względem wpływu na środowisko i klimat akustyczny otoczenia.

\section{Przepustowość skrzyżowań z wyspą centralną}

Przepustowość skrzyżowania $\left(\mathrm{C}_{\mathrm{sk}}\right)$ jest definiowana jako suma natężeń ruchu na wszystkich wlotach skrzyżowania $\mathrm{w}$ sytuacji, gdy na jednym $\mathrm{z}$ nich osiągnięto stan nasycenia (tzw. wlot krytyczny). Zależy ona od wielu czynników związanych z drogą, ruchem pojazdów, zachowaniami i decyzjami kierowców oraz pieszych, różniących się w zależności od kultury, kraju, warunków lokalnych [15]. Skutkuje to między innymi wieloma metodami określania przepustowości, różnymi w zależności od typu skrzyżowania, 
np.: amerykański HCM [16], niemiecki HBS [17], metoda kanadyjska [18], metoda polska $[19,20,21]$. Nowe formy geometrii i organizacji ruchu skrzyżowań (np. ronda turbinowe, skrzyżowania z przemieszczonym skrętem w lewo (ang. DLT lub CFI), skrzyżowania z wyspą centralną sterowane wielofazowym programem sygnalizacji) oraz zmiany w parku samochodowym skutkują ciągłą potrzebą aktualizacji istniejących metod [15]. Polska metoda obliczania przepustowości skrzyżowań z sygnalizacją świetlną z 2004 roku [19] podaje sposób określania przepustowości i oceny warunków ruchu skrzyżowania z wyspą centralną. Zasadnicze obliczenia powinny być jednak poprzedzone sprawdzeniem warunku wystarczającej przepustowości wewnętrznych powierzchni akumulacji względem natężeń relacji skrętu w lewo. Brak spełnienia tego warunku skutkuje w praktyce przepełnieniem wewnętrznych powierzchni akumulacji co prowadzi do zakłóceń w ruchu i znacznego ograniczenia przepustowości wlotów oraz całego skrzyżowania. W takiej sytuacji dalsze stosowanie metody obliczeń podanej w instrukcji [19] jest niepoprawne.

\subsection{Przepustowość wewnętrznych powierzchni akumulacji}

Zgodnie z instrukcją [19] przepustowość pasów na wprost w obrębie wewnętrznych powierzchni akumulacji (obliczona jako iloczyn ich pojemności wyrażonej liczbą pojazdów oraz liczby cykli w godzinie) powinna być większa od natężenia ruchu pojazdów relacji skrętu w lewo korzystających z tych pasów (1):

$$
\mathrm{F}_{\mathrm{a}} \cdot \frac{3600}{\mathrm{~T}} \geq \mathrm{Q}_{\mathrm{L}} \cdot\left(1+\mathrm{U}_{\mathrm{c}}\right), \quad \mathrm{F}_{\mathrm{a}}=\frac{\mathrm{L}_{\mathrm{akum}}}{\mathrm{L}_{\text {poj }}} \cdot \mathrm{n}
$$

gdzie: $F_{a}$ - pojemność wewnętrznej zatoki akumulacji $[\mathrm{P}]$ obliczana jako iloraz długości pasów na wprost $\mathrm{w}$ obrębie wewnętrznej zatoki akumulacji ( $\mathrm{L}_{\text {akum }}$ ) i długości stanowiska pojazdu $\left(\mathrm{L}_{\mathrm{poj}}\right)$ zależnej od $\mathrm{U}_{\mathrm{c}}$ wymnożony przez liczbę pasów ruchu na wprost $(\mathrm{n}) \mathrm{w}$ obrębie powierzchni akumulacji; T - długość cyklu sygnalizacji [s]; QL - natężenie relacji skrętu w lewo korzystającej z zatoki akumulacji $[\mathrm{P} / \mathrm{h}]$; $\mathrm{U}_{\mathrm{c}}$ - udział procentowy pojazdów ciężarowych w relacji skrętu w lewo [-].

Dodatkowo obliczając średnią liczbę pojazdów skręcających w lewo z wlotu skrzyżowania na cykl sygnalizacji, należy określić prawdopodobną maksymalną ich liczbę (korzystając z tabeli zamieszczonej w instrukcji [19]), która powinna być mniejsza od pojemności wewnętrznej powierzchni akumulacji (2).

$$
\mathrm{N}_{\text {sr }}=\frac{\mathrm{Q}_{\mathrm{L}} \cdot \mathrm{T}}{3600} \Rightarrow \mathrm{N}_{\max } \leq \mathrm{F}_{\mathrm{a}}
$$

gdzie: $\mathrm{N}_{\text {śr }}$ - średnia liczba pojazdów skręcających w lewo z wlotu skrzyżowania w czasie cyklu sygnalizacji, [P]; $\mathrm{N}_{\max }{ }^{-}$maksymalna liczba pojazdów skręcających w lewo z wlotu skrzyżowania w czasie cyklu sygnalizacji (określona z 95\% prawdopodobieństwem), [P].

Na podstawie warunków (1) i (2) oraz pracy [4] sporządzono nomogram, który może być pomocny przy optymalizowaniu wielkości wyspy centralnej i długości cyklu sygnalizacji względem natężenia relacji skrętu w lewo - Rys. 1. 


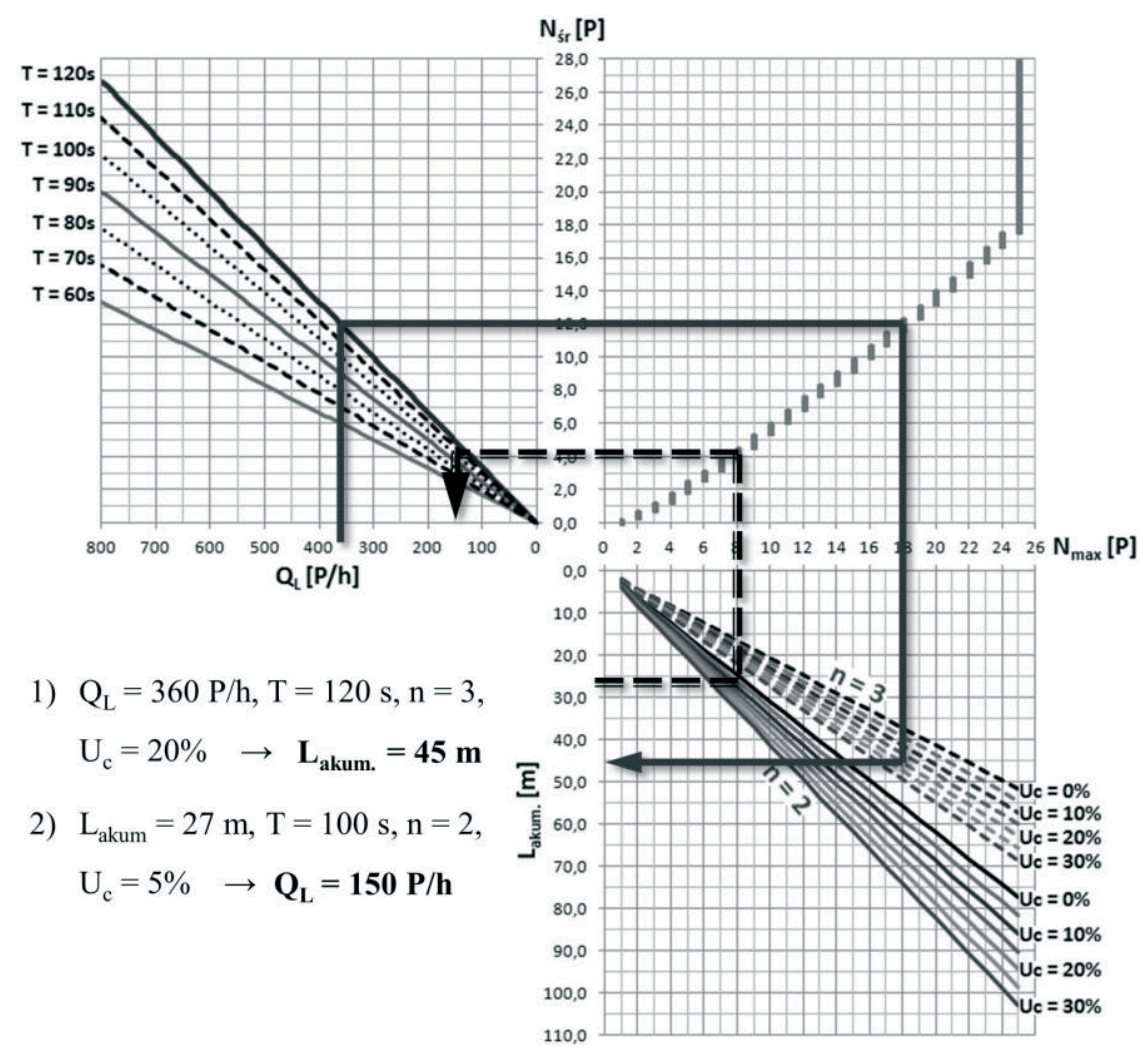

Rys. 1. Nomogram do ustalania wielkości wyspy centralnej z uwagi na wymagania relacji skrętu w lewo

Spełnienie obu warunków (1) i (2) jest konieczne do prowadzenia dalszych obliczeń przepustowości wlotów skrzyżowania z wyspą centralą. Należy jednak zauważyć, że zapis warunku (1) odpowiada sytuacji 2-fazowych programów sygnalizacji świetlnej i nie uwzględnia możliwego wzrostu przepustowości powierzchni akumulacji w wyniku zastosowania programu wielofazowego i wydłużenia długość światła zielonego na przebiegu dominującej relacji skrętu w lewo (np. otwarcie zjazdu z wewnętrznej powierzchniach akumulacji przy jednocześnie otwartym zasadniczym wlocie i zamkniętym kolizyjnym wlocie - Rys. 2). Taka sytuacja powoduje, że znacznie większa liczba pojazdów relacji QL może przejechać skrzyżowanie podczas jednego cyklu sygnalizacji niż wynikałoby to $\mathrm{z}$ samej pojemności $\mathrm{F}_{\mathrm{a}}$ powierzchni akumulacji. $\mathrm{Z}$ tego powodu należy dokonać uzupełnienia warunku (1), które pozwoli na poprawne określenie przepustowości zatok akumulacji przy programach sygnalizacji innych niż 2-fazowe. Problem jest jednak dość skomplikowany a rozwiązanie każdorazowo zależy od schematu faz i programu sygnalizacji. W sposób ogólny można zapisać, że uzupełnienie warunku (1) stanowi pewna liczba pojazdów relacji skrętu w lewo opuszczających skrzyżowanie w dodatkowym czasie pomiędzy otwarciem/zamknięciem wlotów i zatok akumulacji dla danej relacji względem zamknięcia/otwarcia kolizyjnych wlotów i zatok akumulacji. Pewną propozycję uzupełnienia warunku (1) wraz $\mathrm{z}$ obliczeniami przedstawiono $\mathrm{W}$ pracy [5]. Dla powierzchni akumulacji o pojemności od 8 do 10 pojazdów, wydłużenie światła zielonego na przebiegu relacji skrętu w lewo o 10 sekund spowodowało wzrost przepustowości powierzchnia akumulacji o 25-30\%, natomiast wydłużenie o 15 sekund - wzrost o 50-60\%. 

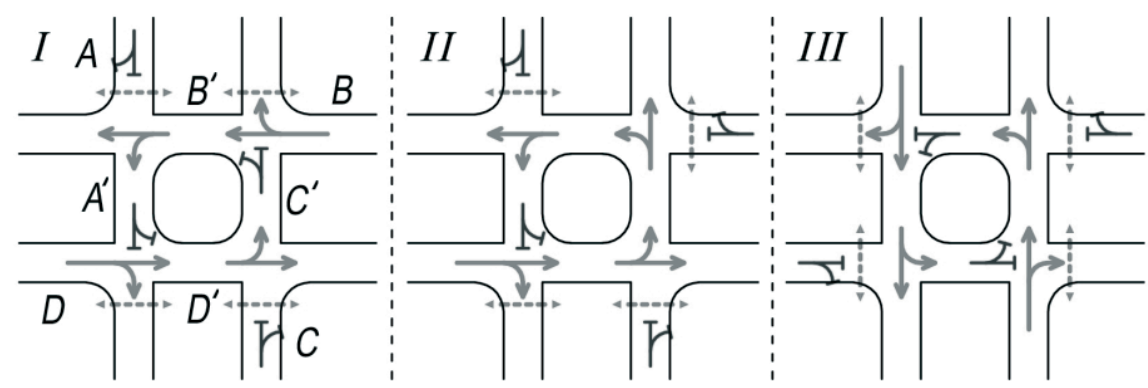

Rys. 2. Układ faz programu sygnalizacji świetlnej na skrzyżowaniu z wyspą centralną wydłużającego długość światła zielonego na przebiegu relacji skrętu w lewo z wlotu D

W celu potwierdzenia uzyskanych obliczeń przeprowadzono mikrosymulację ruchu w programie PTV Vissim. Zmodyfikowano 2-fazowy program sygnalizacji świetlnej (Rys. 3) wydłużając o $10 \mathrm{~s}$ czas otwarcia wlotu północnego A i zatoki akumulacji A’ leżącej na przedłużeniu tego wlotu (przy zamkniętym wlocie południowym C i otwartej zatoce D' oznaczenia jak na rysunku 2). Na rysunku 4 przedstawiono fragment symulacji ruchu pokazujący jak wprowadzona modyfikacja wpłynęła na przepustowość wewnętrznej powierzchni akumulacji D', z której korzystają pojazdy skręcające w lewo z wlotu A. Obliczona pojemność zatoki D’ wynosi 10 pojazdów. Model ruchu wykazał, że ustawiło się na niej 11 pojazdów (Rys. 4a), które następnie opuściły skrzyżowanie po otwarciu zjazdu z tej zatoki (Rys. 4b). W wyniku wprowadzonego wydłużenia czasu otwarcia wlotu A i zatoki A', dodatkowych 5 pojazdów relacji skrętu w lewo $\mathrm{z}$ wlotu A przejechało skrzyżowanie w tym samym cyklu sygnalizacji (Rys. 4c). Na tej podstawie obliczono, że dla tego przypadku przepustowość powierzchni akumulacji wzrosła o $150 \mathrm{P} / \mathrm{h}$ (wzrost o 45\%).

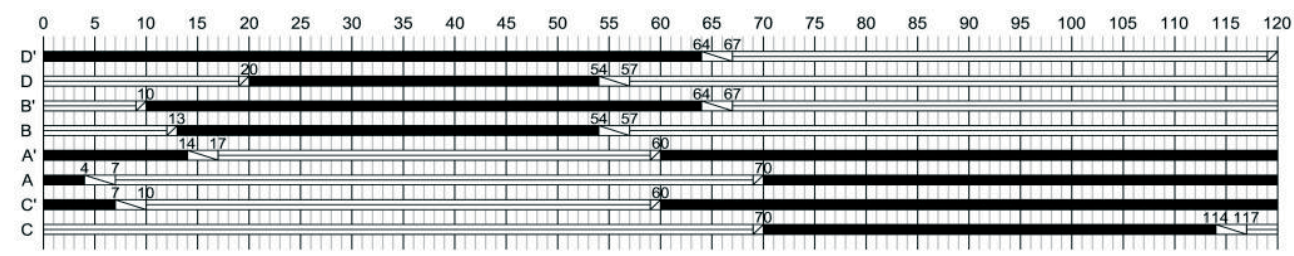

Rys. 3. Program sygnalizacji wydłużający o $10 \mathrm{~s}$ czas otwarcia wlotu A i zatoki A’ względem wlotu C
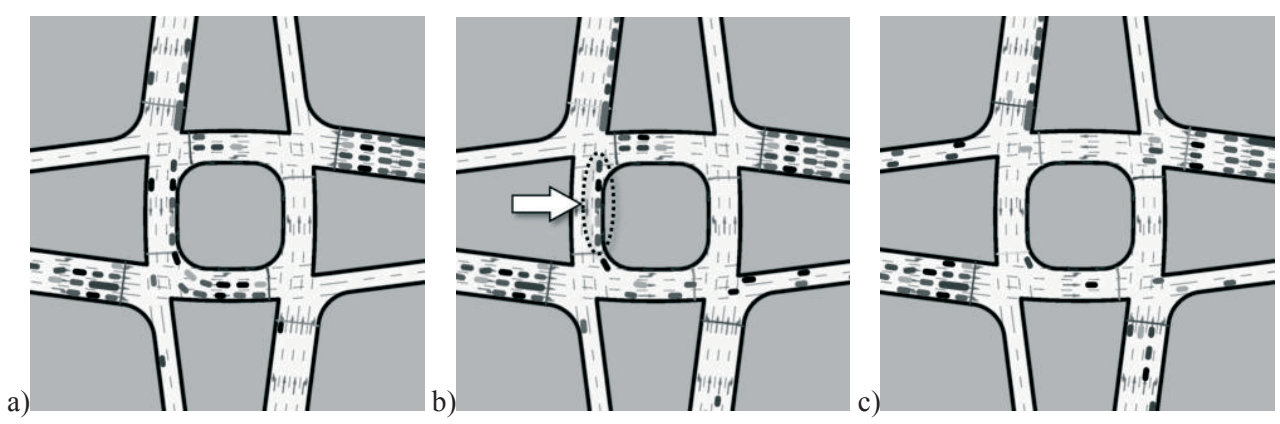

Rys. 4. Przebieg mikrosymulacji ruchu na analizowanym skrzyżowaniu z wyspą centralną z wydłużeniem długości światła zielnego o $10 \mathrm{~s}$ na przebiegu relacji skrętu w lewo z wlotu północnego (A) 


\subsection{Porównanie przepustowości skrzyżowań $z$ wyspą centralną $i$ innych typów skrzyżowań}

W oparciu o polską metodę obliczania przepustowości skrzyżowań drogowych MOP2004 [19, 20, 21] przeprowadzono analizę porównawczą przepustowości 3 rodzajów czterowlotowych skrzyżowań:

- skrzyżowanie skanalizowane bez sygnalizacji świetlnej (SbS) - wloty B i D nadrzędne z wydzielonymi pasami skrętu w lewo; wloty A i C: znak A-7; pełna kanalizacja wlotów;

- rondo małe 1-pasowe o średnicy zewnętrznej $\mathrm{D}_{\mathrm{z}}=32 \mathrm{~m}(\mathrm{R}-1 \mathrm{~L})$ oraz rondo średnie 2-pasowe o $\mathrm{D}_{\mathrm{z}}=50 \mathrm{~m} \mathrm{z}$ dwupasowymi wlotami i wylotami (R-2L);

- skrzyżowanie z wyspą centralną sterowane sygnalizacją świetlną o średnicy wyspy centralnej $\mathrm{D}_{\mathrm{w}}=39 \mathrm{~m}$ (długość $\left.\mathrm{L}_{\mathrm{akum}}=35 \mathrm{~m}\right) ; 4$ pasy ruchu na wlotach $\mathrm{w}$ tym 2 pasy dla relacji na wprost i po jednym pasie dla relacji skrętnych; 3 pasy dookoła wyspy centralnej w tym 2 pasy dla relacji na wprost i jeden dla relacji SL. Obliczenia wykonano dla dwóch programów sygnalizacji świetlnej o długości cyklu $\mathrm{T}=120 \mathrm{~s}$ : nr 1 (SzWC-1), który jest programem 2-fazowym (Rys. 5) oraz nr 2 (SzWC-2), w którym dodano fazę wydłużającą o $10 \mathrm{~s}$ światło zielone na przebiegu relacji skrętu w lewo z wlotu A (Rys. 3).

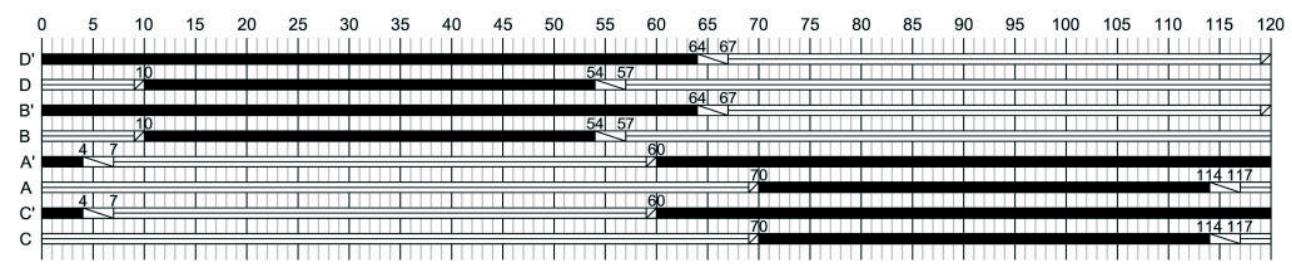

Rys. 5. 2-fazowy program sygnalizacji świetlnej dla analizowanego skrzyżowania z wyspą centralną

Przyjęto następujące założenia do obliczeń:

- wloty oznaczone od A do D poczynając od kierunku północnego zgodnie z ruchem wskazówek zegara;

- 3 warianty rozkładu ruchu na skrzyżowaniu (W.I - W.III) i 4 warianty rozkładu ruchu na relacje na wlocie (Tab. 1)

Tabela 1. Rozkład ruch na wloty i relacje skrzyżowania

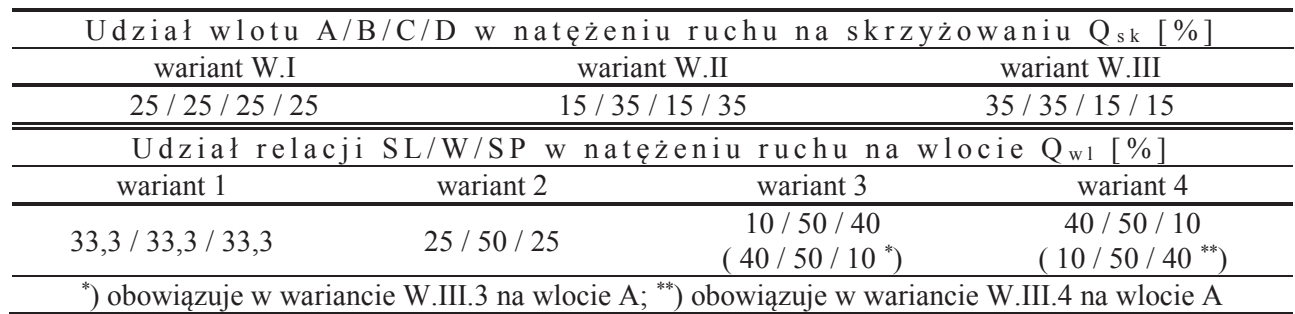

- w obliczeniach analizowano wpływ udziału pojazdów ciężarowych $U_{c}$ na przepustowość skrzyżowania (wartość $U_{c}$ od $0 \%$ do $30 \%$ z czego połowa to pojazdy ciężarowe wieloczłonowe; wartość $U_{c}$ jednakowa dla wszystkich relacji i wlotów);

- stałe natężenie ruchu pieszego na przejściach dla pieszych: $\mathrm{Q}_{\text {ped }}=300$ osób/h. 
W przypadku 2-fazowego programu sygnalizacji, korzystając ze wzorów (1) i (2) obliczono, że maksymalne natężenie relacji skrętu lewo przy którym nie nastąpi przepełnienie zatok akumulacji wynosi w zależności od $\mathrm{U}_{\mathrm{c}}$ od 300 do $184 \mathrm{E} / \mathrm{h}$. Biorąc z kolei pod uwagę prawdopodobną maksymalną liczbę pojazdów jaka może dojechać na wewnętrzną powierzchnię akumulacji, natężenie relacji skrętu w lewo nie powinno być większe niż $184 \mathrm{P} / \mathrm{h}$ (dla $\mathrm{U}_{\mathrm{c}}<11,75 \%$ ) oraz $139 \mathrm{P} / \mathrm{h}\left(\right.$ dla $\left.\mathrm{U}_{\mathrm{c}}>11,75 \%\right)$. Otrzymane wartości maksymalnych natężeń relacji skrętu w lewo uwzględniono w dalszych obliczeniach przepustowości skrzyżowań. Wyniki tych obliczeń przedstawiono w tabeli 2.

Tabela 2. Wyniki obliczeń przepustowości skrzyżowań $\mathrm{C}_{\text {sk }}$

\begin{tabular}{|c|c|c|c|c|c|}
\hline \multirow{2}{*}{ Wariant } & \multicolumn{5}{|c|}{ Zakres przepustowości skrzyżowania $\mathrm{C}_{\mathrm{sk}}[\mathrm{P} / \mathrm{h}]$ w zależności od $\mathrm{U}_{\mathrm{c}}(0-30 \%)$} \\
\hline & $\mathrm{SbS}$ & $\mathrm{R}-1 \mathrm{~L}$ & $\mathrm{R}-2 \mathrm{~L}$ & SzWC-1 & SzWC-2 \\
\hline W.I.1 & $1616-1368$ & $2592-2112$ & $3900-3240$ & $5160-3974$ & $3692-2840$ \\
\hline W.I.2 & $1552-1320$ & $2592-2112$ & $3900-3240$ & $6825-5245$ & $4876-3748$ \\
\hline W.I.3 & $1744-1484$ & $2856-2296$ & $4408-3616$ & $6564-5046$ & $5104-3926$ \\
\hline W.I.4 & $1412-1196$ & $2392-1964$ & $3528-2956$ & $4253-3272$ & $3045-2346$ \\
\hline W.II.1 & $1736-1496$ & $2106-1686$ & $3278-2674$ & $3686-2836$ & $2640-2032$ \\
\hline W.II.2 & $1680-1460$ & $2142-1712$ & $3354-2728$ & $4860-3740$ & $3480-2682$ \\
\hline W.II.3 & $1912-1676$ & $2354-1848$ & $3798-3036$ & $4688-3605$ & $3646-2803$ \\
\hline W.II.4 & $1500-1296$ & $1980-1600$ & $3032-2496$ & $3038-2340$ & $2175-1673$ \\
\hline W.III.1 & $1404-1170$ & $1964-1586$ & $3002-2470$ & $3686-2836$ & $3368-2598$ \\
\hline W.III.2 & $1362-1140$ & $1936-1568$ & $2944-2432$ & $4860-3740$ & $4448-3420$ \\
\hline W.III.3 & $1360-1144$ & $2086-1672$ & $3236-2646$ & $3038-2340$ & $3906-3003$ \\
\hline W.III.4 & $1392-1158$ & $1816-1480$ & $2716-2261$ & $3038-2340$ & $2786-2140$ \\
\hline
\end{tabular}

Otrzymane wyniki potwierdzają, że skrzyżowania z wyspą centralną charakteryzują się bardzo wysokimi wartościami przepustowości. W przypadku równomiernych rozkładów ruchu największe wartości przepustowości otrzymano dla programu 2-fazowego (SzWC-1). Potwierdziły to również analizy prowadzone w ramach pracy [12]. Większe zróżnicowanie w ruchu, zwłaszcza duże natężenia relacji skrętu w lewo prowadzą do istotnego obniżenia przepustowości skrzyżowania a w przypadku wariantów W.II.4, W.III.3 i W.III.4 przepustowość skrzyżowania SzWC-1 jest niemal równa lub nawet niższa od przepustowości ronda R-2L. Analizowany wielofazowy program sygnalizacji świetlnej (SzWC-2), wydłużający czas światła zielonego o $10 \mathrm{~s}$ na przebiegu relacji skrętu w lewo z wlotu A, okazał się lepszym rozwiązaniem jedynie w przypadku wariantu W.III.3, w którym relacja skrętu w lewo z wlotu A była dominującą na skrzyżowaniu. W pozostałych wariantach program ten był gorszym rozwiązaniem (niekiedy nawet od ronda R-2L) z uwagi na niedopasowanie względem natężeń ruchu na wlotach i relacjach skrzyżowania.

\section{Wpływ skrzyżowań z wyspą centralną na klimat akustyczny}

Skrzyżowania drogowe są źródłem wyższych poziomów hałasu w porównaniu z odcinkami międzywęzłowymi, co wynika ze zdecydowanie większych natężeń ruchu pojazdów oraz z przerywanego charakteru ruchu (częste zatrzymania i przyspieszenia pojazdów) [1]. Różnorodna geometria i lokalizacja wlotów mają bardzo duży wpływ na dalsze kształtowanie klimatu akustycznego w otoczeniu skrzyżowania. W pracy [22] dowiedziono, że może to być przyczyną znacznych równic w poziomach hałasu w obrębie różnych wlotów tego samego skrzyżowania (osiągających nawet $6 \mathrm{~dB}$ ). Inną przyczyną tak 
dużych różnic może być również nierównomierny rozkład ruchu na skrzyżowaniu oraz udział i struktura kierunkowa pojazdów hałaśliwych na poszczególnych wlotach skrzyżowania (np. przy „załamanym” przebiegu przez skrzyżowanie dróg o charakterze tranzytowych) [22]. Poziom hałasu zależy również od warunków ruchu panujących na skrzyżowaniu [2] a także może zależeć od typu skrzyżowania a ściślej - od charakteru ruchu. Dotychczasowe badania dowodzą, że poziom hałasu w otoczeniu rond może być mniejszy nawet o 4$6 \mathrm{~dB}$ w stosunku do skrzyżowań $[23,24]$. Powodem tej różnicy jest płynny charakter ruchu na rondach oraz wyniesiona ponad jezdnię wyspa środkowa ronda (zwykle o około 1,5 m), która przysłaniając pewne części jezdni oraz wlotów ronda przyczynia się do obniżenia hałasu w jego otoczeniu [25]. Charakter ruchu oraz poziom hałasu w obszarze skrzyżowania może być również kształtowany poprzez środki uspokojenia ruchu. Wyniki badań [26] dowodzą, że zastosowanie wyniesionych powierzchni skrzyżowań z sinusoidalnie kształtowanymi najazdami, może istotnie obniżyć prędkość pojazdów, zmniejszyć liczbę zatrzymań oraz gwałtownych przyspieszeń czego konsekwencją jest redukcja hałasu.

W celu określenia wpływu rodzaju skrzyżowania na poziom hałasu w jego otoczeniu, przeanalizowano wyniki pomiarów równoważnego poziomu dźwięku $\mathrm{L}_{\text {Aeq }}$ prowadzonych wraz z pomiarami natężenia ruchu w latach 2012-2015 w otoczeniu 4 skrzyżowań z wyspą centralną w Białymstoku (oznaczonych: W2, W3, W5 i W6), ronda dwupasowego (R1) i skrzyżowania skanalizowanego z sygnalizacją świetlną (S1). Pomiary $\mathrm{L}_{\text {Aeq }}$ wykonano cyfrowymi analizatorami dźwięku kl. $1 \mathrm{w}$ punktach położonych promieniście do punktu centralnego skrzyżowania (pomiędzy wlotem a wylotem) na wysokości 1,5 m nad poziomem jezdni, w odległości 10 i $20 \mathrm{~m}$ od krawędzi zewnętrznego pasa ruchu (Rys. 6). Jeżeli pozwalały na to warunki terenowe, w niektórych przypadkach wykonano również pomiary w odległościach 30 i $40 \mathrm{~m}$ od krawędzi zewnętrznego pasa ruchu. Uzyskane w taki sposób dane stanowiły podstawę do określenia wartości $\mathrm{L}_{\text {Aeq }} \mathrm{W}$ punktach położonych w odległości od 40 do 70 m od środka badanych skrzyżowań.
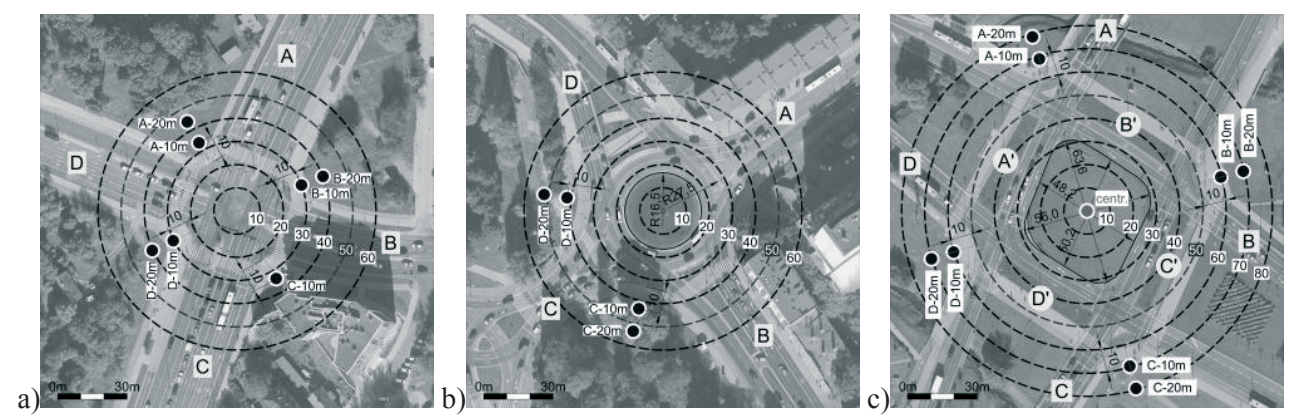

Rys. 6. Geometria skrzyżowań i lokalizacja punktów pomiarów hałasu: a) S1, b) R1, c) W2

Na rysunku 7 przedstawiono wybrane wyniki pomiarów $L_{\text {Aeq }}$ w odległości 10 i 20 m od krawędzi jezdni dla 3 typów skrzyżowań przy zbliżonych 4 parametrach ruchu: natężenie ruchu na skrzyżowaniu $\left(\mathrm{Q}_{\mathrm{sk}}\right)$ i na wlocie $\left(\mathrm{Q}_{\mathrm{wl}}\right)$, udział procentowy pojazdów ciężkich $\left(\mathrm{U}_{\mathrm{c}}\right)$ oraz autobusów ( $\mathrm{U}_{\text {bus }}$ ) w ruchu na skrzyżowaniu. Otrzymane wartości różnią się między sobą w zależności od skrzyżowania. Największe różnice otrzymano w przypadku rond (R) gdzie poziomy hałasu były od 0,5 do 3,5 dB niższe niż w przypadku skrzyżowań z sygnalizacją świetlną ( $\mathrm{S}$ i W), przy czym większe różnice odnotowano przy niższych obciążeniach ruchem. Przyczyną tak dużych różnić jest charakter i specyfika ruchu na rondach - ruch nieprzerywany oraz prędkości w zakresie 20-30 km/h. Różnice te zmniejsza- 
ją się wraz ze zwiększeniem obciążenia ronda (pogorszenie warunków ruchu). W grupie skrzyżowań $\mathrm{z}$ sygnalizacją świetlną, wartości $\mathrm{L}_{\text {Aeq }}$ otrzymane $\mathrm{w}$ otoczeniu skrzyżowań z wyspą centralną (W) były od około 0,5 do $1,0 \mathrm{~dB}$ niższe niż przy typowych skrzyżowaniach skanalizowanych z sygnalizacją świetlną (S). Przyczyną tej różnicy może być geometria obu typów skrzyżowań. Rozsunięcie jezdni poprzez wyspę centralną oraz wyspy dzielące powoduje oddalenie niektórych jezdni a tym samym źródeł hałasu. W przypadku „typowej” budowy skrzyżowania skanalizowanego, źródła hałasu są bardziej skoncentrowane wokół środka skrzyżowania, co może prowadzić do większych poziomów hałasu w ich otoczeniu. Przedstawione na rysunku 7 wyniki pomiarów $\mathrm{L}_{\text {Aeq }}$, dobrze ilustrują wpływ charakteru ruchu oraz geometrii 3 typów skrzyżowań na poziomy hałasu w ich otoczeniu.

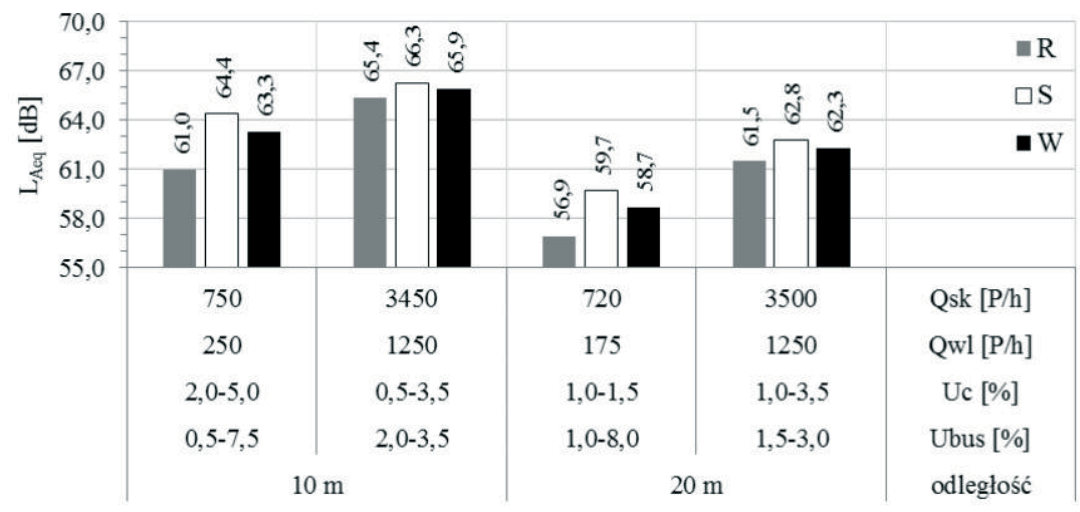

Rys. 7. Wybrane wyniki pomiarów LAeq w odległości 10 i 20 m od krawędzi jezdni dla 3 typów skrzyżowań

Na podstawie wyników pomiarów dla dwóch przedziałów natężenia ruchu na skrzyżowaniu $\mathrm{Q}_{\text {sk: }}$ 500-1000 P/h (dla R i W) i 2000-2500 P/h (dla S i W) oraz przy udziale pojazdów ciężarowych $\mathrm{U}_{\mathrm{c}}=0-10 \%$, obliczono wartości $\mathrm{L}_{\text {Aeq }} \mathrm{W}$ odległościach od 40 do $70 \mathrm{~m}$ od środka skrzyżowania. Na rysunku 8 podano wartości różnic pomiędzy $\mathrm{L}_{\text {Aeq }} \mathrm{W}$ odległościach 40, 50, 60 i $70 \mathrm{~m}$ od środka skrzyżowań z wyspą centralną W2, W3, W5, W6 w odniesieniu do skrzyżowania skanalizowanego S1 (Rys. 8a) lub ronda R1 (Rys. 8b).
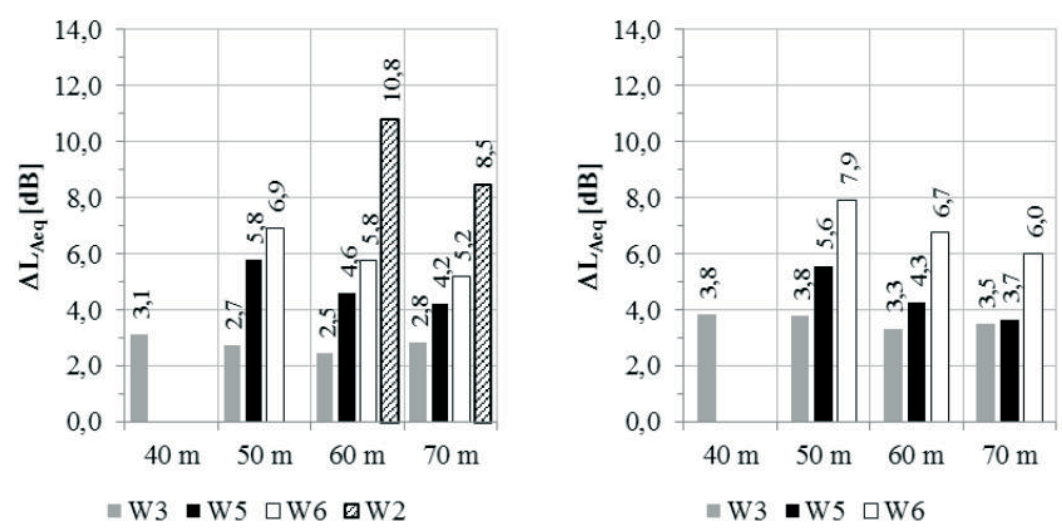

Rys. 8. Różnice w poziomach $\mathrm{L}_{\text {Aeq }} \mathrm{w}$ otoczeniu wlotów: a) skrzyżowania skanalizowanego S1 i skrzyżowań z wyspą centralną W2, W3, W5 i W6, b) ronda R1 i skrzyżowań z wyspą centralną W3, W5 i W6 
Uzyskane różnice w wartościach $\mathrm{L}_{\text {Aeq }}$ jednoznacznie wskazują jak bardzo typ skrzyżowania i jego geometria mogą wpływać na zasięg oddziaływania hałasu. Przy porównywalnych parametrach ruchu drogowego, w odległości $60 \mathrm{~m}$ od punktu centralnego badanych skrzyżowań, wartości $\mathrm{L}_{\text {Aeq }}$ dla skrzyżowań z wyspą centralną były wyższe od $2,5 \mathrm{~dB}$ do $10,8 \mathrm{~dB}$ w porównaniu ze skrzyżowaniem skanalizowanym z sygnalizacją świetlną S1 oraz wyższe od 3,3 dB do 6,7 dB w odniesieniu do analizowanego ronda R1. Przyczyną takich różnic jest zajętość terenu przez skrzyżowanie wynikająca z jego geometrii i budowy ale również charakterystyka odbywającego się na nim ruchu. Obszar terenu zajmowany przez skrzyżowania z wyspą centralną (określony za pomocą promienia okręgu o środku leżącym w środku wyspy do punktów pomiaru hałasu znajdujących się $10 \mathrm{~m}$ od krawędzi jezdni) może wynosić nawet do $70 \mathrm{~m}$. Dla porównania małe i średnie ronda zajmują obszary o promieniu od 20 do $40 \mathrm{~m}$, duże ronda - od 40 do $50 \mathrm{~m}$, natomiast ,typowe” skrzyżowania - od 25 do około $40 \mathrm{~m}$. Skrzyżowania z wyspą centralną są zatem dużo gorszym rozwiązaniem z uwagi na zajętość terenu i zasięg oddziaływania hałasu lecz pod względem przepustowości, warunków ruchu i wpływu na klimat akustyczny mogą okazać się lepszym rozwiązaniem szczególnie przy bardzo dużych natężeniach ruchu.

\section{Wnioski}

Przeprowadzone analizy przepustowości wewnętrznych powierzchni akumulacji wykazały, że zastosowanie wielofazowych programów sygnalizacji, wydłużających długość światła zielonego na przebiegu dominującej relacji skrętu w lewo, może przyczynić się do istotnego wzrostu przepustowości tych powierzchni wynoszącego od 20 do nawet $60 \%$ (w zależności od długości wydłużenia światła zielonego). Opracowany model ruchu potwierdził powyższe wnioski. Jest to szczególnie istotne ponieważ, poprawne funkcjonowanie skrzyżowania $\mathrm{z}$ wyspą centralną jest uzależnione od sprawnie działających wewnętrznych powierzchni akumulacji. Obliczenia porównawcze przepustowości różnych typów skrzyżowań, potwierdziły, że skrzyżowania z wyspą centralną charakteryzują się najwyższymi wartościami przepustowości - dla przyjętych założeń, największa wartość jaką otrzymano w obliczeniach wynosiła około 6800 P/h. Przyjęty 2-fazowy program sygnalizacji świetlnej okazał się dobrym rozwiązaniem w większości przypadków obliczeniowych, szczególnie przy stosunkowo równomiernym rozkładzie ruchu na skrzyżowaniu i wlotach. Program wielofazowy był lepszym w przypadku dużego natężenia relacji w lewo z wlotu A.

Analizy wpływu skrzyżowań na poziom hałasu w ich otoczeniu wykazały, że zarówno typ skrzyżowania jak również charakter ruchu mają istotne znaczenie. Płynny charakter ruchu na rondach sprzyjał mniejszym o 0,5 do $3,5 \mathrm{~dB}$ poziomom hałasu w ich otoczeniu niż w przypadku skrzyżowań z sygnalizacją świetlną. Z kolei zajętość terenu przez skrzyżowanie, wynikająca $z$ jego geometrii, wpływa istotnie na zasięg oddziaływania hałasu. Przy porównywalnych parametrach ruchu, w punkcie położonym w odległości $60 \mathrm{~m}$ od środka skrzyżowania, dla skrzyżowań z wyspą centralną uzyskano poziomy hałasu wyższe o 10,8 dB niż w przypadku odpowiednio - skrzyżowania z sygnalizacją świetlną i ronda.

Badania zostały zrealizowane $w$ ramach pracy $n r$ MB/WBiIŚ/5/2013 na Politechnice Białostockiej i sfinansowane ze środków na naukę MNiSW. 


\section{Literatura}

1 Bohatkiewicz J. Badania czynników powodujących zwiększenie poziomu hałasu w otoczeniu skrzyżowań drogowych, w: Ochrona środowiska i estetyka w drogownictwie, Stowarzyszenie Inżynierów i Techników Komunikacji RP, Lublin 2000, 199-210.

2 Tracz M., Bohatkiewicz J. Effects of traffic conditions on traffic noise at signalized intersection. 2nd European Conference on Noise Control - Euro-Noise'95, Vol. 1. Lyon 1995.

3 Tracz M., Chodur J., Gaca S. Wytyczne projektowania skrzyżowań drogowych. Część I i II, GDDP, Warszawa 2001.

4 Tracz M., Chodur J. Performance and Safety of Roundabouts with Traffic Signals. Procedia - Social and Behavioral Sciences 53 (2012) 789-800.

5 Motylewicz M. Skrzyżowania z wyspą centralną i wielofazową sygnalizacją świetlną - propozycja udoskonalenia metody oceny ich przepustowości, w: Wiedza i eksperymenty w budownictwie, Gliwice 2014, 565-572.

6 Kania L. Sygnalizacja świetlna na skrzyżowaniach z wyspą centralną. Magazyn Autostrady 5/2006, 24-32.

7 Hoffmann A. Programowanie wielofazowych sygnalizacji świetlnych. Skrzyżowania z wyspą centralną. Bezpieczne Drogi 6/2004.

8 Gumińska L., Kustra W. Funkcjonowanie skrzyżowań z wyspą centralną ze zmienną wielkością wewnętrznych powierzchni akumulacji, w: Problemy komunikacyjne miast w warunkach zatłoczenia motoryzacyjnego. IX Konferencja Naukowo-Techniczna, Poznań-Rosnówko, 19-21.06.2013.

9 Gumińska L., Kustra W. The influence of accumulation area and the length of pedestrian route on functioning of roundabouts with traffic signals. Transportation Research Procedia 3 (2014) 10411050 .

10 Chrobot P., Krukowicz T., Wilk P. Funkcjonowanie powierzchni akumulacyjnych na skrzyżowaniach z wyspą centralną. Logistyka 6/2011, 447-456.

11 Narożny J.: Sygnalizacja a wyspy centralne. Magazyn Autostrady 1-2/2007, 14-18.

12 Motylewicz M., Gardziejczyk W. Badanie i ocena warunków ruchu na skrzyżowaniach z wyspą centralną na przykładzie Białegostoku. Transport Miejski i Regionalny 10/2012, 8-15.

13 Bielewska M. Charakterystyka polskich skrzyżowań z wyspą centralną. Polskie Drogi 4/2005, wkładka: Bezpieczeństwo i Inżynieria Ruchu, 6-11.

14 Szczuraszek T. i in. Bezpieczeństwo ruchu miejskiego. WKt, Warszawa 2006.

15 Ostrowski K., Chodur J. Performance and reliability of signalised intersections, w: Recent advances in civil engineering: Road and transportation engineering, Inżynieria lądowa 483, Kraków 2015.

16 Highway Capacity Manual 2010. TRB, Washington D.C., USA 2010.

17 HBS 2001. Handbuch für die Bemessung von Straßenverkehrsanlagen. Forschungsgesellschaft für Straßen- und Verkehrswesen e.V., Köln 2001.

18 Tepley S. Canadian capacity guide for signalized intersections. The Institute of Transportation Engineering, Canada 2008.

19 Tracz M. i in. Metoda obliczania przepustowości skrzyżowań z sygnalizacją świetlną. GDDKiA, Warszawa 2004.

20 Chodur J. i in. Metoda obliczania przepustowości skrzyżowań bez sygnalizacji świetlnej. GDDKiA, Warszawa 2004.

21 Tracz M. i in. Metoda obliczania przepustowości rond. GDDKiA, Warszawa 2004.

22 Motylewicz M., Gardziejczyk W. Hałas od ruchu samochodowego w otoczeniu skrzyżowań. Budownictwo i Architektura, Vol. 13, nr 1 (2014), 137-147.

23 Silence - Practitioner Handbook for Local Noise Action Plans. Kolonia 2008.

24 Covaciu, D., Florea, D., Timar, J., 2015. Estimation of the noise level produced by road traffic in roundabouts. Applied Acoustics 98, 43-51.

25 Biernacki S. Badania poziomu hałasu na wybranych rondach w Krakowie i Rybniku. Praca magisterska. Kraków 2001.

26 Bohatkiewicz J. i in. Wpływ uspokojenia ruchu na klimat akustyczny w otoczeniu ulic. Budownictwo i Architektura, Vol. 13, nr 1 (2014), 235-252. 


\title{
Signalized roundabouts - capacity, traffic conditions and their influence on noise levels
}

\author{
Marek Motylewicz \\ Division of Road Engineering, Faculty of Civil and Environmental Engineering, \\ Bialystok University of Technology,e-mail:m.motylewicz@pb.edu.pl
}

\begin{abstract}
Signalized roundabouts are the suggested solution in road design, mainly due to the presence of large inner areas of accumulation for vehicles turning left, which, if designed correctly, result in a high capacity of the entire solution. In recent years, due to a dynamic growth in traffic and the deterioration of its conditions, many cities in Poland, including Bialystok, have begun rebuilding their existing intersections into signalized roundabouts. The proper functioning of such roundabouts depends on the parameters of the traffic lights signal plan and the capacity of the inner areas of accumulation, which should be larger than the traffic volume turning left. The article suggests methods of determining the capacity of these areas in the case of multi-phase signal plans, and the sample calculations have been supported by the results of traffic microsimulation modelling. Comparative calculations of the capacity of signalized roundabouts, roundabouts and intersections with no signalization have also been performed. The article also contains an analysis of the influence of signalized roundabouts on the noise level in their vicinity in relation to the results of the equivalent sound level measurements conducted in the vicinity of other types of intersections.
\end{abstract}

Keywords: intersection, central island, roundabout, capacity, traffic noise. 